\title{
Impact of soils and cropping systems on mineral composition of dry cacao beans
}

\author{
Q. R. de Araujo ${ }^{1,2 *}$, V. C. Baligar ${ }^{3}$, G. A. H. de A. Loureiro ${ }^{1}$, J. O. de Souza Júnior ${ }^{2}$, N. B.
} Comerford $^{4}$

${ }^{1}$ Cacao Research Center (CEPEC) at the Executive Commission for the Cacao Farming Plan (CEPLAC), $\mathrm{km}$ 22 Ilhéus-Itabuna Highway. 45600-970, Itabuna, Bahia, Brazil. ${ }^{2}$ Department of Agricultural and Environmental Sciences at the State University of Santa Cruz (UESC), km 16 Ilhéus-Itabuna Highway. 45662-000, Ilhéus, Bahia, Brazil. ${ }^{3}$ USDA-ARS Beltsville Agricultural Research Center, Beltsville, Maryland, USA. ${ }^{4}$ North Florida Research and Education Center, University of Florida, Quincy, FL 32351, USA. *Corresponding author: quintino.raraujo@agricultura.gov.br

\begin{abstract}
In view of its high economic value, cacao (Theobroma cacao L.) scientists are seeking technological innovations that increases production and improve quality of cacao beans. The objective of this study was to characterize the mineral ( $, \mathrm{K}, \mathrm{P}, \mathrm{Ca}, \mathrm{Mg}, \mathrm{Si}, \mathrm{Fe}, \mathrm{Mn}, \mathrm{Zn}, \mathrm{Cu}, \mathrm{Cd}, \mathrm{Ba}$ ) composition of cacao beans of clone PH-16 grown in different soil types (Argisols, Cambisols and Latosols) and cropping systems (Cacao Cabruca, Cacao x Erythrina and Cacao x Rubber). With the exception of nitrogen, $\mathrm{K}$ was the mineral element most accumulated by cacao beans of PH-16 clone. Potassium, $\mathrm{Ca}, \mathrm{P}$ and $\mathrm{Mg}$ mineral content of dry cacao beans were positively correlated with each other and showed similarity in clusters of average contents in relationship to the different cropping sites. Silicon content in cacao beans is proportionately close to the content of macronutrients. Variations in the content of $\mathrm{Mn}, \mathrm{Fe}, \mathrm{Zn}, \mathrm{Cu}, \mathrm{Cd}$ and $\mathrm{Ba}$ in cacao beans were related to the cropping sites because these mineral elements did not show any significant correlations with each other. Barium contents observed in this study correspond to levels of other micronutrients. In four sites, Cd content was higher than the limit set by the European Union.
\end{abstract}

Keywords: Theobroma cacao L., cacao quality, agricultural traceability, potentially toxic elements 


\section{Introduction}

Cacao (Theobroma cacao L.) is an important commodity crop grown mainly in tropical regions located between latitudes $20^{\circ} \mathrm{N}$ and $20^{\circ} \mathrm{S}$ of the equator. According to FAO (2017) cacao is cultivated over 10 million ha of land area in the tropical countries with world production over 4 million tones. After post-harvest processing, the cacao beans are the main commercial product of cacao tree. Cacao beans and their products are the raw materials for making chocolate, a food that is widely consumed worldwide, whose industrial demands have increased substantially every year (FAO, 2017). Therefore, current investments and technological innovations in the cacao sector are intended to increase crop productivity and quality of cacao beans.

The chemical composition of the beans is regarded as the basis for defining cacao bean quality (Araujo et al., 2014; Loureiro et al., 2016). In this context, the mineral composition of cacao beans is highlighted by their potential to differentiate genotypes with different nutritional and environmental requirements (Malavolta et al., 1984; Ekpa et al., 1993; Aikpokpodion, 2010; Muniz et al., 2013; Aikpokpodion et al., 2013; Loureiro et al., 2016). Many mineral elements are linked to the quality of cacao beans, such as macronutrients ( $, \mathrm{P}, \mathrm{K}, \mathrm{S}, \mathrm{Ca}, \mathrm{Mg}$ ) (Malavolta et al., 1984; Aikpokpodion, 2010; Pinto, 2013; Araujo et al., 2014; Loureiro, 2016), Si (Araujo et al., 2014; Loureiro, 2016), and micronutrients (Fe, Mn, $\mathrm{Zn}, \mathrm{Cu}$, B, Mo, Cl, Ni) (Malavolta et al., 1984; Kohiyama et al., 1992; Aikpokpodion, 2010; Pinto, 2013; Yanus et al. 2014). Whereas potentially toxic elements (As, $\mathrm{Ba}, \mathrm{Cd}, \mathrm{Cu}, \mathrm{Ni}, \mathrm{Pb}$ ) in beans reduce quality factors (Lee and Low, 1985; Kohiyama et al., 1992; Aikpokpodion et al., 2013; Araujo et al., 2014; Loureiro, 2016; Yanus et al. 2014; EU, 2013, 2014). A recent study (Bertoldi et al., 2016) described 56 macro-, micro- and trace elements (Ag, Al, As, B, Ba, Be, Bi, $\mathrm{Ca}, \mathrm{Cd}, \mathrm{Ce}, \mathrm{Co}, \mathrm{Cr}, \mathrm{Cs}, \mathrm{Cu}, \mathrm{Dy}, \mathrm{Er}, \mathrm{Eu}, \mathrm{Fe}, \mathrm{Ga}, \mathrm{Gd}, \mathrm{Ge}$, $\mathrm{Hg}, \mathrm{Ho}, \mathrm{K}, \mathrm{La}, \mathrm{Li}, \mathrm{Mg}, \mathrm{Mn}, \mathrm{Mo}, \mathrm{Na}, \mathrm{Nd}, \mathrm{Ni}, \mathrm{P}, \mathrm{Pb}$, Pd, Pr, Rb, Sb, Se, Sm, Sn, Sr, Te, Th, Ti, Tl, Tm, U, $\mathrm{V}, \mathrm{Y}, \mathrm{Yb}, \mathrm{Zn}$ ) in cocoa beans of different geographical origins. According Colombo et al. (2012), chocolate has the potential to provide significant amount of minerals in the human diet because cocoa is extremely rich source of many essential minerals. Cinquanta et al. (2016) described some essential and non-essential mineral elements (Al, Ba, Ca, Cr, Cu, Fe, K, Mg, Mn, $\mathrm{Mo}, \mathrm{Na}, \mathrm{Ni}, \mathrm{P}, \mathrm{Se}, \mathrm{Zn}$ ) for human nutrition in cocoa beans and different chocolate products, highlighting the potential of dark chocolate as a source of magnesium, zinc and selenium. Because of their importance, some of these mineral attributes were included in the development of the methodology of the cacao quality index (Araujo et al., 2014).

The fundamental strategy to increase cacao production in Bahia is the adaptation of tolerant genotypes for Moniliophthora perniciosa (Stahel) Aime \& Phillips-Mora, the main fungal phytopathogen that causes the disease 'witches' broom. Porto Hibrido 16 (PH16) is a clonal variety tolerant to 'witches' broom, selected from a population of crosses between cacao trees of the Forastero (Amazon) and Trinitario groups (whose parents are unknown), located at Porto Hibrido farm in São José da Vitória, Bahia, Brazil (Cruz et al., 2013). Recent studies have reported detailed information about the mineral composition of cacao beans of this clone cultivated in different environmental conditions (Muniz et al., 2013; Pinto, 2013; Loureiro, 2016).

The objective of this study was to investigate the influence of different sites, represented by different soils and cropping systems on the composition of mineral elements of dry cacao beans of PH-16 clone. 


\section{Material and Methods}

\subsection{Sites and sampling}

Twelve study sites were located in the humid zone of the cacao region of Bahia, Brazil (Table 1). The Thornthwaite climatic classification was: B4r A', B3r
A', B2r A', B2r B', B1r A', B1r' A', B1w A'. These sites (Table 1) were planted with $\mathrm{PH}-16$ cacao clone under different cropping systems, with a range of shade tree densities and across three soil classes: Argisols, Cambisols and Latosols. Soils were classified in the Brazilian System of Soil Classification (SiBCS) (Santos et al., 2013).

Table 1. Cropping sites represented by soil types, and cultivated with $\mathrm{PH}-16$ cacao clone in the cacao growing region of Bahia, Brazil

\begin{tabular}{|c|c|c|c|c|c|c|}
\hline $\begin{array}{l}\text { Cropping } \\
\text { Site }\end{array}$ & $\begin{array}{l}\text { Geographic } \\
\text { Coordinates }\end{array}$ & City & Acronym of the SiBCS & Soil Classification & $\begin{array}{l}\text { Cropping } \\
\text { Systems }\end{array}$ & $\begin{array}{l}\text { Shade Tree } \\
\text { Densities } \\
(\text { trees ha-1) }\end{array}$ \\
\hline 1 & $\begin{array}{l}13^{\circ} 40^{\prime} 30^{\prime \prime} \mathrm{S} \\
39^{\circ} 14^{\prime} 27^{\prime \prime} \mathrm{W}\end{array}$ & Nilo Peçanha & LAd cam & Latosol Yellow Dystrophic cambisolic & $\begin{array}{c}\text { Cacao } \mathrm{x} \\
\text { Rubber Tree }\end{array}$ & 150 \\
\hline 2 & $\begin{array}{l}13^{\circ} 44^{\prime} 38^{\prime \prime} \mathrm{S} \\
39^{\circ} 30^{\prime} 10^{\prime \prime} \mathrm{W}\end{array}$ & Gandú & PVAd & Argisol Red-Yellow Dystrophic tipic & $\begin{array}{c}\text { Cacao } \mathrm{x} \\
\text { Erythrina }\end{array}$ & 60 \\
\hline 3 & $\begin{array}{l}13^{\circ} 45^{\prime} 21^{\prime \prime} \mathrm{S} \\
39^{\circ} 20^{\prime} 25^{\prime \prime} \mathrm{W}\end{array}$ & $\begin{array}{l}\text { Pirai do } \\
\text { Norte }\end{array}$ & PVAd & Argisol Red-Yellow Dystrophic abrupt & Cabruca** & 60 \\
\hline 4 & $\begin{array}{l}13^{\circ} 46^{\prime} 07.0^{\prime \prime} \mathrm{S} \\
39^{\circ} 17^{\prime} 52.0^{\prime \prime} \mathrm{W}\end{array}$ & Ituberá & LAd & Latosol Yellow Dystrophic tipic & $\begin{array}{c}\text { Cacao } \mathrm{x} \\
\text { Rubber Tree }\end{array}$ & 350 \\
\hline 5 & $\begin{array}{l}13^{\circ} 51^{\prime} 08^{\prime \prime} \mathrm{S} \\
39^{\circ} 17^{\prime} 54^{\prime \prime} \mathrm{W}\end{array}$ & Ituberá & LVAd & Latosol Red-Yellow Dystrophic tipic & $\begin{array}{c}\text { Cacao } \mathrm{x} \\
\text { Rubber Tree }\end{array}$ & 400 \\
\hline 6 & $\begin{array}{l}14^{\circ} 31^{\prime} 14^{\prime \prime} \mathrm{S} \\
39^{\circ} 15^{\prime} 45^{\prime \prime} \mathrm{W}\end{array}$ & Uruçuca & PVAe cam & Argisol Red-Yellow Eutrophic cambisolic & Cabruca** & 50 \\
\hline 7 & $\begin{array}{l}14^{\circ} 51^{\prime} 36^{\prime \prime} \mathrm{S}, \\
39^{\circ} 14^{\prime} 42^{\prime \prime} \mathrm{W}\end{array}$ & Itabuna & CXd & Cambisol Haplic Dystrophic tipic & Cabruca** & 35 \\
\hline 8 & $\begin{array}{l}14^{\circ} 51^{\prime} 47^{\prime \prime} \mathrm{S} \\
39^{\circ} 06^{\prime} 47^{\prime \prime} \mathrm{W}\end{array}$ & Ilhéus & LVAd arg & Latosol Red-Yellow Dystrophic argisolic & Cabruca** & 70 \\
\hline 9 & $\begin{array}{l}15^{\circ} 17^{\prime} 04^{\prime \prime} \mathrm{S}, \\
39^{\circ} 28^{\prime} 43^{\prime \prime} \mathrm{W}\end{array}$ & Arataca & PAd lat & Argisol Yellow Dystrophic latosolic & Cabruca** & 35 \\
\hline 10 & $\begin{array}{l}15^{\circ} 23^{\prime} 08^{\prime \prime} \mathrm{S} \\
39^{\circ} 26^{\prime} 04^{\prime \prime} \mathrm{W}\end{array}$ & Camacan & PVAd & Argisol Red-Yellow Dystrophic tipic & Cabruca** & 35 \\
\hline 11 & $\begin{array}{l}15^{\circ} 23^{\prime} 15.1^{\prime \prime} \mathrm{S}, \\
39^{\circ} 25^{\prime} 48.6 " \mathrm{~W}\end{array}$ & Camacan & PVA ali & Argisol Red-Yellow Alitic tipic & Cabruca** & 35 \\
\hline 12 & $\begin{array}{l}16^{\circ} 29^{\prime} 02^{\prime \prime} \mathrm{S} \\
39^{\circ} 23^{\prime} 56^{\prime \prime} \mathrm{W}\end{array}$ & Porto Seguro & PVAd coe & $\begin{array}{l}\text { Argisol Red-Yellow Dystrophic Cohesive } \\
\text { abrupt }\end{array}$ & $\begin{array}{c}\text { Cacao } \mathrm{x} \\
\text { Rubber Tree }\end{array}$ & 400 \\
\hline
\end{tabular}

*SiBCS - Brazilian System of Soil Classification (Santos et al., 2013).**Cabruca is an ecological system of agroforestry cultivation where cacao trees are grown under native trees of the Atlantic Forest of Southern of Bahia state. 
Cacao sampling occurred on November of 2008. This month was chosen because it is representative of the second harvest period (August 2008 to January 2009). Each study site (approximately 1 hectare) was divided into three collection areas, characterized by the same soil and same cropping system. Fifty mature cacao pods were combined into a single composite sample from each of the three sampling areas for the postharvest processing of fermentation and drying. The origin of each sample of pods and beans corresponds to a properly identified and classified soil in each study site.

\subsection{Post-harvest processing}

Beans with mucilage from 50 cacao pods were fermented in Styrofoam boxes $(30 \times 20 \times 30 \mathrm{~cm})$ with a capacity of approximately $8 \mathrm{~kg}$. Seeds were fermented for 168 hours (7 days) with peak temperature of 51 ${ }^{\circ} \mathrm{C}$ occurring on the 3 rd day of fermentation. After being fermented, cacao beans were continuously dried in forced ventilation oven with temperatures ranging between 35 and $45{ }^{\circ} \mathrm{C}$ for 192 hours ( 8 days). After being dried, the cacao beans showed approximately $7 \%$ moisture content. The dry cacao beans were manually peeled with tweezers for a complete separation between the seed coat and endosperm, and only the endosperm (cotyledons and embryo) were milled for chemical analysis. In this study the term dry cacao beans refers to the endosperm of dry cacao beans.

\subsection{Mineral elements}

To determine the composition of mineral elements, the endosperm of cacao beans was milled in a multiprocessor and stored in $50 \mathrm{ml}$ glass vials. The total nitrogen was determined according to the 31.1.08 method of micro-Kjeldahl (AOAC, 2005) slightly modified by Brazilian Agricultural Research Corporation (Embrapa) (Carmo et al., 2000); $0.2 \mathrm{~g}$ of milled cacao bean endosperm was used. For determination of mineral elements $\mathrm{P}, \mathrm{K}, \mathrm{Ca}, \mathrm{Mg}, \mathrm{Fe}, \mathrm{Mn}, \mathrm{Cu}, \mathrm{Zn}, \mathrm{Ba}$, $\mathrm{Cd}$ and $\mathrm{Pb}, 0.2 \mathrm{~g}$ of milled cacao bean endosperm was used for acid digestion by perchloric nitric solubilization analysed according to an adaptation of the method described by Embrapa (Carmo et al., 2000). Acid digestion of bean tissue was performed with a solution of $4 \mathrm{ml}$ of concentrated $\mathrm{HNO}(65 \%)$ and $2 \mathrm{ml}$ of $\mathrm{HClO}$ $(70 \%)$. The material was placed in the digester block with an initial temperature of $50^{\circ} \mathrm{C}(30$ minutes) and a final temperature of $120^{\circ} \mathrm{C}(90$ minutes $)$.

For determination of Si content, $0.1 \mathrm{~g}$ of milled endosperm of cacao beans was used for alkaline digestion. Alkaline digestion was performed using the method described by Korndörfer et al. (2004). Briefly, $0.1 \mathrm{~g}$ samples of plant tissue were placed in plastic tubes followed by the addition of $2 \mathrm{ml}$ of $\mathrm{H}_{2} \mathrm{O}_{2}(30 \%)$ and 3 $\mathrm{ml}$ of $\mathrm{NaOH}(1: 1)$. The tubes were shaken and placed in a water bath at $90{ }^{\circ} \mathrm{C}$ for one hour. Also, during this period the tubes were stirred to prevent leakage due to oxidation caused by $\mathrm{NaOH}$. Then the tubes were autoclaved for one hour at $123{ }^{\circ} \mathrm{C}$ and $1.5 \mathrm{~atm}$ pressure. After removing the autoclaved tube, $45 \mathrm{ml}$ of distilled water were added and the contents transferred into a plastic cup and, left to rest overnight.

Potassium, $\mathrm{K}, \mathrm{Ca}, \mathrm{Mg}, \mathrm{Fe}, \mathrm{Mn}, \mathrm{Cu}$ and $\mathrm{Zn}$ were determined by inductively coupled plasma optical emission spectrometry (ICP-OES). Barium, Cd and $\mathrm{Pb}$ were determined by inductively coupled plasma mass spectrometry (ICP-MS). Silicon was determined by colorimetry (Korndörfer et al., 2004). An aliquot of $1 \mathrm{ml}$ of digested matter was placed in plastic cups, $19 \mathrm{ml}$ of distilled water, $1 \mathrm{ml} \mathrm{HCl} \mathrm{(1:}$ 1) and $2 \mathrm{ml}$ of ammonium molybdate were added, followed by a mild agitation. The Si present in the material forms $\mathrm{H}_{4} \mathrm{SiO}_{4}$ which develops yellow color in the presence of ammonium molybdate in acidic medium. After 5 to $10 \mathrm{~min}, 2 \mathrm{ml}$ of oxalic acid were added, followed again by mild agitation. After two 
minutes, the reading was done in spectrophotometer at a wavelength of $410 \mathrm{~nm}$. Quantification was made through a standard curve made from a $1000 \mathrm{ppm}$ of $\mathrm{Si}$ standard solution obtained with pure sodium silicate.

\subsection{Statistical analysis}

A completely randomized experimental design was used, with 12 cropping sites characterized by different soil types and cropping systems, with three replicates at each site. The replicate measurements were taken during identical but different experimental runs, which were randomized. This multiple response measurement was taken at the same combination of factor settings (geographic coordinate, cropping system and shade tree densities), and mainly characterized by soil type. Statistical procedures used in this study were performed in R (R Development Core Team, 2016): Shapiro-Wilk normality test and Bartlett homoscedasticity test, Kolmogorov-Smirnov normality test (Lilliefors correction), Analysis of Variance and ran the Scott-Knott test to group means. The biplots in Principal Component Analysis (PCA) were performed with the package 'bpca' (Faria et al., 2015).

\section{Results}

The variables corresponding to mineral composition of PH-16 cacao clone beans were subjected to tests of normality and homoscedasticity related to residues. Where appropriate phosphorus $(\mathrm{P})$, potassium $(\mathrm{K})$, silicon $(\mathrm{Si})$, iron $(\mathrm{Fe})$, zinc $(\mathrm{Zn})$, copper $(\mathrm{Cu})$ and barium $(\mathrm{Ba})$ were transformed by the average and standard deviation in order to meet the normal distribution assumptions of the Analysis of Variance. It was not necessary for the mineral elements: calcium $(\mathrm{Ca})$, magnesium $(\mathrm{Mg})$, cadmium $(\mathrm{Cd})$.

Significant differences in the averages of $\mathrm{P}, \mathrm{K}, \mathrm{Ca}$ and Si contents in dry cacao beans of PH-16 clone were associated with the cropping sites (Table 2). No significant differences were observed in the $\mathrm{N}$ and $\mathrm{Mg}$ contents in dry cacao beans (Table 2).

No statistical differences were observed between the averages of $\mathrm{N}$ content in dry cacao beans (Table 2); however, the overall range of average contents was 21.32 to $33.03 \mathrm{~g} \mathrm{~kg}^{-1}$ (Table 2).

The group of cropping sites with the highest averages of $\mathrm{P}$ content in cacao beans showed values between 2.68 and $2.94 \mathrm{~g} \mathrm{~kg}^{-1}$, and the group with the lowest averages showed values between 2.28 and $2.55 \mathrm{~g} \mathrm{~kg}^{-1}$ (Table 2). Sites that were geographically close to each other were brought together in the group representing high $\mathrm{P}$ content, such as sites 7 (Cambisol Haplic Dystrophic tipic), 8 (Latosol Red-Yellow Dystrophic argisolic), 9 (Argisol Dystrophic latosolic), 10 (Argisol Red-Yellow Dystrophic tipic) and 11 (Argisol Red-Yellow Alitic tipic).

The highest averages of $\mathrm{K}$ content in cacao beans in this study ranged between 7.90 and $8.90 \mathrm{~g} \mathrm{~kg}^{-1}$ while the lowest averages correspond to the group with values between of 6.98 and $7.48 \mathrm{~g} \mathrm{~kg}^{-1}$ (Table 2). The sites 1 (Latosol Yellow Dystrophic cambisolic), 2 (Argisol Red-Yellow Dystrophic tipic), 5 (Latosol Red-Yellow Dystrophic tipic), 9 (Argisol Dystrophic latosolic), 10 (Argisol Red-Yellow Dystrophic tipic) and 11 (Argisol Red-Yellow Alitic tipic) belong to the higher K content (Table 2). The sites 3 (Argisol RedYellow Dystrophic abrupt), 4 (Latosol Yellow Dystrophic tipic), 6 (Argisol Red-Yellow Eutrophic cambisolic), 7 Cambisol Haplic Dystrophic tipic), 8 and 12 (Latosol Red-Yellow Dystrophic argisolic), belong to the group of lower average $\mathrm{K}$ contents (Table 2).

The group with highest averages of Ca content showed values between 2.70 and $2.86 \mathrm{~g} \mathrm{~kg}^{-1}$, while the lowest averages showed values between 2.53 and $2.66 \mathrm{~g} \mathrm{~kg}^{-1}$ (Table 2). Except for site 8 (Latosol Red-Yellow Dystrophic argisolic), the ranking of sites for $\mathrm{Ca}$ contents corresponded to that for $\mathrm{K}$ contents (Table 2). 
Also, with the exception of sites 7 (Cambisol Haplic Dystrophic tipic) and 8, there is the same group for the averages of $\mathrm{P}$ content. At different cropping sites, no statistical differences were observed between the averages of $\mathrm{Mg}$ content in dry cacao beans (Table 2); however, the overall range of average contents was 1.74 to 2.41 (Table 2 ).
Average values of Si content in dry cacao beans were similar to the macronutrient content of $\mathrm{P}, \mathrm{K}$ and $\mathrm{Ca}$, and varied according to the study sites (Table 2). The group of cropping sites with the highest averages of $\mathrm{Si}$ content showed values between 1.80 and $2.30 \mathrm{~g} \mathrm{~kg}^{-1}$, and the group with the lowest averages showed values between 0.80 and $1.47 \mathrm{~g} \mathrm{~kg}^{-1}$ (Table 2).

Table 2. Analysis of variance, Scott-Knott test and descriptive analysis of the mineral elements $\mathrm{N}, \mathrm{K}, \mathrm{P}, \mathrm{Ca}, \mathrm{Mg}$ and $\mathrm{Si}$ of dry cacao beans of PH-16 clone

\begin{tabular}{|c|c|c|c|c|c|c|c|}
\hline \multirow{3}{*}{ Source } & \multirow{3}{*}{ DF } & $\mathrm{N}$ & $\mathrm{K}$ & $\mathrm{P}$ & $\mathrm{Ca}$ & $\mathrm{Mg}$ & $\mathrm{Si}$ \\
\hline & & \multicolumn{6}{|c|}{$\mathrm{g} \mathrm{kg}^{-1}$} \\
\hline & & \multicolumn{6}{|c|}{ Mean Square } \\
\hline $\mathrm{CS}^{1}$ & 11 & $10.12^{\mathrm{ns}}$ & $0.10^{*}$ & $1.03 * *$ & $0.02^{*}$ & $0.03^{\mathrm{ns}}$ & $0.56^{*}$ \\
\hline Error & 24 & 9.40 & 0.04 & 0.31 & 0.02 & 0.02 & 0.26 \\
\hline Total & 35 & & & & & & \\
\hline \multicolumn{2}{|l|}{ CV $(\%)$} & 12.1 & 7.7 & 7.1 & 3.8 & 7.3 & 35.5 \\
\hline \multicolumn{2}{|c|}{ Cropping Sites $^{1}$} & \multicolumn{6}{|c|}{ Average \pm Standard Deviation $(n=3)$} \\
\hline \multicolumn{2}{|c|}{01 LAd cam } & $27.07 \pm 2.64$ & $8.07 \pm 0.67$ a & $2.85 \pm 0.17$ a & $2.78 \pm 0.13 a$ & $2.20 \pm 0.14$ & $1.20 \pm 0.40 \mathrm{~b}$ \\
\hline \multicolumn{2}{|l|}{02 PVAd } & $25.14 \pm 3.45$ & $8.08 \pm 0.43$ a & $2.80 \pm 0.14 a$ & $2.75 \pm 0.06 \mathrm{a}$ & $2.23 \pm 0.12$ & $2.10 \pm 1.00 \mathrm{a}$ \\
\hline \multicolumn{2}{|l|}{03 PVAd } & $26.40 \pm 3.73$ & $7.48 \pm 0.32 b$ & $2.55 \pm 0.10 \mathrm{~b}$ & $2.63 \pm 0.08 \mathrm{~b}$ & $2.08 \pm 0.06$ & $1.00 \pm 0.30 \mathrm{~b}$ \\
\hline \multicolumn{2}{|l|}{$04 \mathrm{LAd}$} & $24.81 \pm 2.40$ & $7.40 \pm 0.52 b$ & $2.43 \pm 0.25 \mathrm{~b}$ & $2.65 \pm 0.12 \mathrm{~b}$ & $2.08 \pm 0.23$ & $1.20 \pm 0.40 \mathrm{~b}$ \\
\hline \multicolumn{2}{|l|}{05 LVAd } & $26.08 \pm 0.82$ & $7.90 \pm 0.59 a$ & $2.75 \pm 0.13 a$ & $2.76 \pm 0.09 a$ & $2.03 \pm 0.10$ & $1.17 \pm 0.06 \mathrm{~b}$ \\
\hline \multicolumn{2}{|c|}{06 PVAe cam } & $28.89 \pm 6.24$ & $7.41 \pm 0.43 b$ & $2,28 \pm 0.21 \mathrm{~b}$ & $2.53 \pm 0.12 b$ & $1.85 \pm 0.11$ & $1.17 \pm 0.45 \mathrm{~b}$ \\
\hline \multicolumn{2}{|l|}{$07 \mathrm{CXd}$} & $29.34 \pm 1.96$ & $6.98 \pm 0.19 \mathrm{~b}$ & $2.83 \pm 0.17 \mathrm{a}$ & $2.66 \pm 0.03 \mathrm{~b}$ & $2.10 \pm 0.15$ & $1.90 \pm 0.60 \mathrm{a}$ \\
\hline \multicolumn{2}{|c|}{ 08 LVAd arg } & $29.14 \pm 2.40$ & $7.16 \pm 0.34 \mathrm{~b}$ & $2.73 \pm 0.34 a$ & $2.71 \pm 0.06 \mathrm{a}$ & $2.12 \pm 0.25$ & $2.30 \pm 1.20 \mathrm{a}$ \\
\hline \multicolumn{2}{|l|}{09 PAd lat } & $24.14 \pm 0.82$ & $8.90 \pm 1.58 \mathrm{a}$ & $2.69 \pm 0.37 \mathrm{a}$ & $2.86 \pm 0.23 a$ & $2.17 \pm 0.21$ & $1.20 \pm 0.20 \mathrm{~b}$ \\
\hline \multicolumn{2}{|l|}{10 PVAd } & $25.15 \pm 3.39$ & $8.64 \pm 0.50 \mathrm{a}$ & $2.68 \pm 0.23 a$ & $2.74 \pm 0.04$ a & $2.10 \pm 0.10$ & $0.80 \pm 0.40 \mathrm{~b}$ \\
\hline \multicolumn{2}{|l|}{11 PVA ali } & $25.46 \pm 3.18$ & $8.44 \pm 0.40 \mathrm{a}$ & $2.94 \pm 0.13 \mathrm{a}$ & $2.70 \pm 0.07 a$ & $2.09 \pm 0.06$ & $1.80 \pm 0.10 \mathrm{a}$ \\
\hline \multirow{2}{*}{\multicolumn{2}{|c|}{12 PVAd coe }} & $24.80 \pm 1.67$ & $7.37 \pm 0.27 \mathrm{~b}$ & $2.39 \pm 0.16 \mathrm{~b}$ & $2.59 \pm 0.03 \mathrm{~b}$ & $1.96 \pm 0.15$ & $1.47 \pm 0.15 \mathrm{~b}$ \\
\hline & & \multicolumn{6}{|c|}{ Overall average $(n=36)$} \\
\hline \multicolumn{2}{|c|}{ Mininum } & 21.32 & 6.80 & 2.04 & 2.41 & 1.74 & 0.40 \\
\hline \multicolumn{2}{|c|}{ Average $\pm \mathrm{SD}$} & $26.37 \pm 3.10$ & $7.82 \pm 0.79$ & $2.66 \pm 0.27$ & $2.70 \pm 0.12$ & $2.08 \pm 0.16$ & $1.44 \pm 0.65$ \\
\hline \multicolumn{2}{|c|}{ Maximum } & 33.03 & 10.60 & 3.13 & 3.09 & 2.41 & 3.50 \\
\hline
\end{tabular}

${ }^{1}$ Cropping sites mainly characterized by soil types: 01 LAd cam - Latosol Yellow Dystrophic cambisolic; 02 PVAd - Argisol Red-Yellow Dystrophic tipic; 03 PVAd - Argisol Red-Yellow Dystrophic abrupt; 04 LAd - Latosol Yellow Dystrophic tipic; 05 LVAd - Latosol Red-Yellow Dystrophic tipic; 06 PVAe cam - Argisol Red-Yellow Eutrophic cambisolic; 07 Cxd - Cambisol Haplic Dystrophic tipic; 08 LVAd arg - Latosol Red-Yellow Dystrophic argisolic; 09 PAd lat - Argisol Yellow Dystrophic latosolic; 10 PVAd - Argisol Red-Yellow Dystrophic tipic; 11 PVA ali - Argisol Red-Yellow Alitic tipic; 12 PVAd coe - Argisol RedYellow Dystrophic Cohesive abrupt. DF $=$ Degrees of Freedom. CV = Coefficient of Variation. SD $=$ Standard Deviation. Significance levels by test $\mathrm{F}:(* *)=1 \%$ of error. In bold are highlighted the average clusters positively correlated with cacao quality. 
Figure 1 shows the significant correlations between macronutrients $\mathrm{P}, \mathrm{K}, \mathrm{Ca}$ and $\mathrm{Mg}$ in dry cacao beans. Among the correlations, highlighted in order of absolute value, positive correlations were found between $\mathrm{P}$ and $\mathrm{Mg}(\mathrm{r}=0.84)$ (Figure $1 \mathrm{c})$, between $\mathrm{K}$ and $\mathrm{Ca}(\mathrm{r}=$
0.72) (Figure 1d), between $\mathrm{P}$ and $\mathrm{Ca}(\mathrm{r}=0.66)$ (Figure $1 b)$, and between $\mathrm{Ca}$ and $\mathrm{Mg}(\mathrm{r}=0.66)$ (Figure 1f). Also were observed positive correlations between the mineral content of $\mathrm{P}$ and $\mathrm{K}(\mathrm{r}=0.57)$ (Figure 1a) and between $\mathrm{K}$ and $\mathrm{Mg}(\mathrm{r}=0.57)$ (Figure 1e).
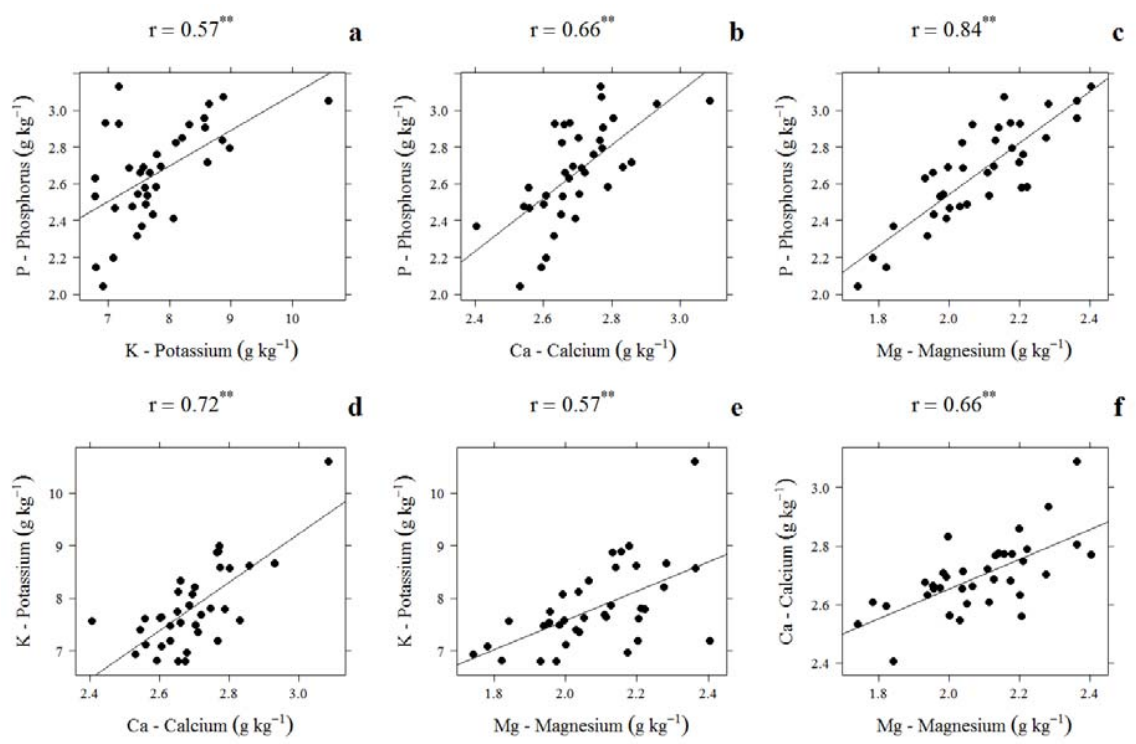

Figure 1. Statistical linear correlations between macronutrients of dry cacao beans of PH-16 clone ( $r=$ Pearson's linear correlation coefficient; ${ }^{* *}$ Significant at $1 \%$ level; $\mathrm{n}=36$ ).

The PCA biplots representing the macronutrients $\mathrm{K}, \mathrm{P}, \mathrm{Ca}$ and $\mathrm{Mg}$ of dry cacao beans of the PH 16 clone are shown in Figures 2 and 3, and vary according to the study sites soils (Figure 2a) and the soil classes (Figure 3a), different cropping systems (Figures $2 b$ and $3 b$ ), the average density of shade trees per hectare (Figure 2b) and the geographic coordinates (Figure 2a and $b$ ).

Table 3 lists the summary of PCA for these macronutrients explored by biplots in Figure 2. In Figure 2 , biplots $\mathrm{a}$ and $\mathrm{b}$ have the same structure between variables and objects because they are the same PCA (Table 3); they were based on the graphical representation of the averages of mineral content in cacao beans. Biplots $a$ and $b$ in Figure 3 also have the same structure between variables and objects (Table 3 ) and were based on the graphical representation of the observations of mineral content in cacao beans corresponding to the all samples of cropping sites represented by soil types. The objects shown in Figure 2a, 2b, 3a and 3b were renamed for interpretation purposes.

The differences observed in average values of $\mathrm{Mn}$, $\mathrm{Fe}, \mathrm{Zn}, \mathrm{Cu}, \mathrm{Cd}$ and $\mathrm{Ba}$ contents of dry cacao beans of PH-16 clone were associated with the differences the cropping sites (Table 4). 

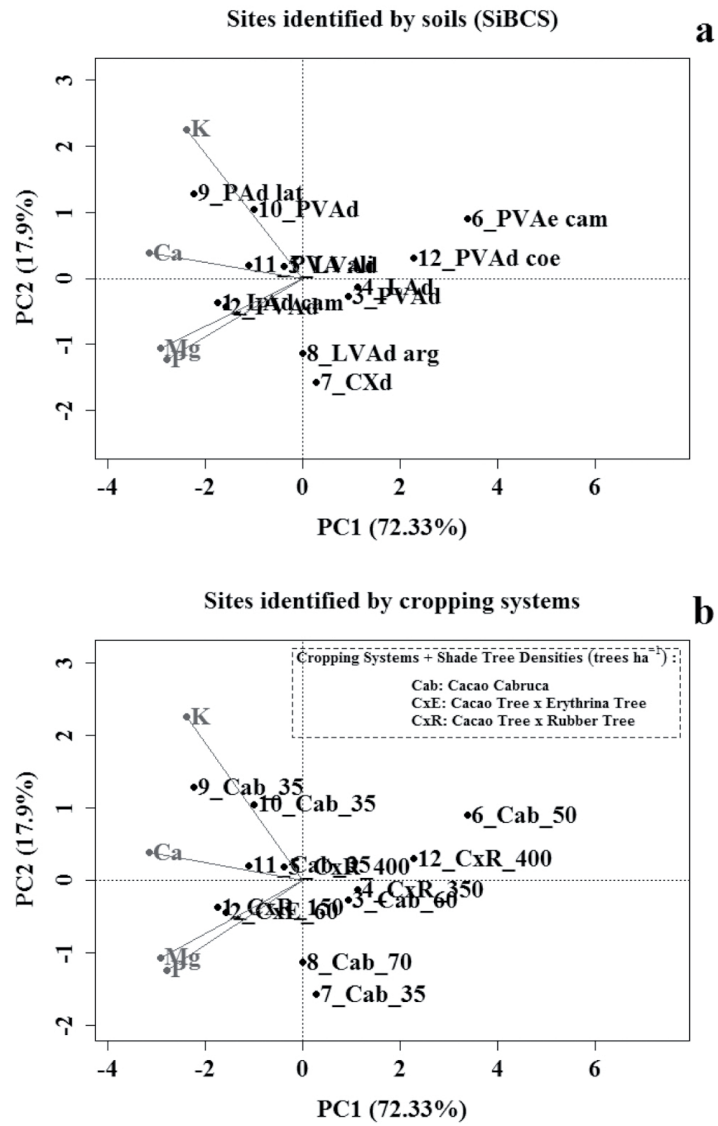

Figure 2. Principal Component Analysis Biplots. Mineral elements of dry cacao beans of the PH-16 clone: Phosphorus (P); Potassium (K); Calcium (Ca); Magnesium (Mg). Field sites identified by soils types (Brazilian System of Soil Classification SiBCS) (a): Latosol Yellow Dystrophic cambisolic (1_LAd cam), Argisol Red-Yellow Dystrophic tipic (2_PVAd), Argisol RedYellow Dystrophic abrupt (3_PVAd), Latosol Yellow Dystrophic tipic (4_LAd), Latosol Red-Yellow Dystrophic tipic (5_LVAd), Argisol Red-Yellow Eutrophic cambisolic (6_PVAe cam), Cambisol Haplic Dystrophic tipic (7_CXd), Latosol Red-Yellow Dystrophic argisolic (8_LVAd arg), Argisol Yellow Dystrophic latosolic (9_PAd lat), Argisol Red-Yellow Dystrophic tipic (10_PVAd), Argisol Red-Yellow Alitic tipic (11_PVA ali), Argisol Red-Yellow Dystrophic Cohesive abrupt (12_PVAd coe). Field sites identified by cropping systems (b). Numbered soils according to the longitudinal direction North-South.
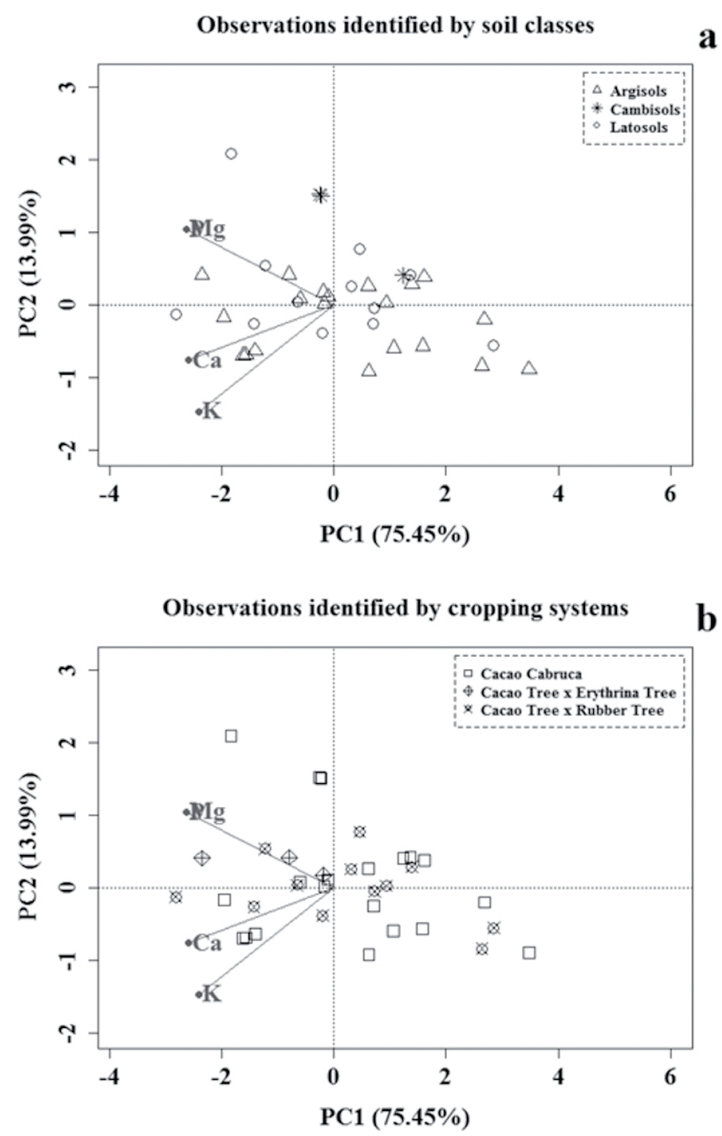

Figure 3. Principal Component Analysis Biplots. Factors indicate the relative weight of the variables on the axes. Mineral elements of dry cacao beans of the PH-16 clone: Phosphorus (P); Potassium (K); Calcium (Ca); Magnesium (Mg). (a) Sample observations identified by soil classes (Brazilian System of Soil Classification). (b) Sample observations identified by cropping systems. 
Table 3. Summary of Principal Component Analysis (PCA) of macronutrients $\mathrm{P}, \mathrm{K}, \mathrm{Ca}$ and $\mathrm{Mg}$ of dry cacao beans of $\mathrm{PH}-16$ clone

\begin{tabular}{|c|c|c|c|c|}
\hline \multirow[t]{2}{*}{ Summary } & \multicolumn{2}{|c|}{$\begin{array}{l}12 \text { soils and cropping systems } \\
\text { with average density of shade trees }\end{array}$} & \multicolumn{2}{|c|}{$\begin{array}{l}\text { All observations by soil types and } \\
\text { cropping systems }\end{array}$} \\
\hline & $\mathrm{PC} 1$ & PC2 & $\mathrm{PC} 1$ & PC2 \\
\hline Phosphorus $-\mathrm{P}$ & -0.49 & -0.44 & -0.51 & 0.47 \\
\hline Potassium - K & -0.42 & 0.80 & -0.47 & -0.66 \\
\hline Calcium - Ca & -0.56 & 0.14 & -0.50 & -0.34 \\
\hline Magnesium - Mg & -0.52 & -0.38 & -0.51 & 0.47 \\
\hline Eigenvalue & 5.64 & 2.81 & 10.28 & 4.42 \\
\hline Retained Variance & 0.72 & 0.18 & 0.75 & 0.14 \\
\hline Accumulated Variance & 0.72 & 0.90 & 0.75 & 0.89 \\
\hline
\end{tabular}

$\mathrm{PC}=$ Principal Component

Table 4. Analysis of variance, Scott-Knott test and descriptive analysis of the mineral elements $\mathrm{Mn}, \mathrm{Fe}, \mathrm{Zn}, \mathrm{Cu}$, $\mathrm{Cd}$ and $\mathrm{Ba}$ of dry cacao beans of $\mathrm{PH}-16$ clone

\begin{tabular}{|c|c|c|c|c|c|c|c|}
\hline \multirow{3}{*}{ Source } & \multirow{3}{*}{ DF } & $\mathrm{Mn}$ & $\mathrm{Fe}$ & $\mathrm{Zn}$ & $\mathrm{Cu}$ & $\mathrm{Cd}$ & $\mathrm{Ba}$ \\
\hline & & \multicolumn{6}{|c|}{$\mathrm{mg} \mathrm{kg}^{-1}$} \\
\hline & & \multicolumn{6}{|c|}{ Mean Square } \\
\hline $\mathrm{CS}^{1}$ & 11 & $90.32 * *$ & $540.72 * *$ & $24.91 *$ & $36.71 * *$ & $18.34 * *$ & $0.31 * *$ \\
\hline Error & 24 & 6.38 & 154.65 & 9.11 & 7.29 & 1.26 & 0.02 \\
\hline Total & 35 & & & & & & \\
\hline $\mathrm{CV}(\%)$ & & 12.1 & 40.9 & 10 & 12.3 & 21.7 & 28.1 \\
\hline \multicolumn{2}{|l|}{ Cropping Sites $^{\mathrm{a}}$} & \multicolumn{6}{|c|}{ Average \pm Standard Deviation $(n=3)$} \\
\hline 01 LAd cam & & $17.81 \pm 1.80 \mathrm{c}$ & $12.01 \pm 1.23 \mathrm{~b}$ & $34.54 \pm 1.16 \mathrm{a}$ & $26.43 \pm 1.01 \mathrm{a}$ & $0.23 \pm 0.06 \mathrm{~d}$ & $2.23 \pm 0.42 \mathrm{e}$ \\
\hline 02 PVAd & & $20.99 \pm 2.27 b$ & $24.17 \pm 8.25 b$ & $30.62 \pm 4.28 \mathrm{a}$ & $19.07 \pm 3.29 b$ & $0.63 \pm 0.21 \mathrm{c}$ & $5.30 \pm 1.95 \mathrm{~d}$ \\
\hline 03 PVAd & & $26.52 \pm 2.04 \mathrm{a}$ & $26.59 \pm 15.25 \mathrm{~b}$ & $26.70 \pm 1.78 b$ & $17.53 \pm 0.74 b$ & $0.63 \pm 0.15 \mathrm{c}$ & $6.47 \pm 0.06 \mathrm{c}$ \\
\hline $04 \mathrm{Lad}$ & & $27.56 \pm 2.75 a$ & $16.60 \pm 10.10 \mathrm{~b}$ & $28.82 \pm 4.97 \mathrm{~b}$ & $22.43 \pm 3.12 \mathrm{a}$ & $0.37 \pm 0.15 d$ & $3.20 \pm 0.60 \mathrm{e}$ \\
\hline 05 LVAd & & $14.79 \pm 2.08 \mathrm{c}$ & $10.95 \pm 0.13 b$ & $30.10 \pm 1.65 a$ & $23.97 \pm 1.36 \mathrm{a}$ & $0.37 \pm 0.15 d$ & $4.33 \pm 0.38 \mathrm{~d}$ \\
\hline 06 PVAe cam & & $28.46 \pm 5.14 \mathrm{a}$ & $58.97 \pm 2.89$ a & $24.19 \pm 0.33 \mathrm{~b}$ & $26.67 \pm 9.13 \mathrm{a}$ & $0.30 \pm 0.10 \mathrm{~d}$ & $8.93 \pm 1.80 \mathrm{~b}$ \\
\hline $07 \mathrm{CXd}$ & & $21.20 \pm 1.54 \mathrm{~b}$ & $28.24 \pm 15.25 \mathrm{~b}$ & $30.47 \pm 1.23 \mathrm{a}$ & $17.97 \pm 0.84 b$ & $0.50 \pm 0.26 \mathrm{c}$ & $11.23 \pm 0.72 \mathrm{a}$ \\
\hline 08 LVAd arg & & $16.00 \pm 1.84 \mathrm{c}$ & $33.79 \pm 4.03 \mathrm{~b}$ & $31.21 \pm 3.01 \mathrm{a}$ & $22.10 \pm 1.95 \mathrm{a}$ & $0.97 \pm 0.15 \mathrm{~b}$ & $6.53 \pm 0.55 \mathrm{c}$ \\
\hline 09 PAd lat & & $27.22 \pm 4.14 \mathrm{a}$ & $31.75 \pm 12.78 \mathrm{~b}$ & $26.60 \pm 2.36 \mathrm{~b}$ & $22.83 \pm 1.19 \mathrm{a}$ & $0.47 \pm 0.06 \mathrm{c}$ & $3.50 \pm 0.95 \mathrm{e}$ \\
\hline 10 PVAd & & $14.77 \pm 1.30 \mathrm{c}$ & $51.27 \pm 35.41$ a & $31.28 \pm 1.16 \mathrm{a}$ & $24.20 \pm 1.55 \mathrm{a}$ & $0.23 \pm 0.15 d$ & $2.67 \pm 0.15 \mathrm{e}$ \\
\hline 11 PVA ali & & $20.63 \pm 1.02 \mathrm{~b}$ & $32.65 \pm 10.02 b$ & $31.82 \pm 3.75 \mathrm{a}$ & $24.50 \pm 1.80 \mathrm{a}$ & $1.33 \pm 0.15 \mathrm{a}$ & $4.80 \pm 1.47 \mathrm{~d}$ \\
\hline \multirow[t]{2}{*}{12 PVAd coe } & & $13.86 \pm 0.16 \mathrm{c}$ & $37.43 \pm 3.54 b$ & $34.34 \pm 6.97 \mathrm{a}$ & $15.53 \pm 1.46 \mathrm{~b}$ & $0.53 \pm 0.12 \mathrm{c}$ & $2.80 \pm 0.10 \mathrm{~d}$ \\
\hline & & \multicolumn{6}{|c|}{ Overall average $(n=36)$} \\
\hline Mininum & & 12.68 & 10.38 & 23.35 & 14.20 & 0.10 & 1.90 \\
\hline Average $\pm \mathrm{SD}$ & & $20.82 \pm 5.72$ & $30.37 \pm 17.92$ & $30.06 \pm 4.05$ & $21.94 \pm 4.39$ & $0.55 \pm 0.34$ & $5.17 \pm 2.78$ \\
\hline Maximum & & 32.86 & 92.02 & 42.38 & 36.20 & 1.50 & 11.70 \\
\hline
\end{tabular}

${ }^{1}$ Cropping sites mainly characterized by soil types: 01 LAd cam - Latosol Yellow Dystrophic cambisolic; 02 PVAd - Argisol Red-Yellow Dystrophic tipic; 03 PVAd - Argisol Red-Yellow Dystrophic abrupt; 04 LAd - Latosol Yellow Dystrophic tipic; 05 LVAd - Latosol Red-Yellow Dystrophic tipic; 06 PVAe cam - Argisol Red-Yellow Eutrophic cambisolic; 07 Cxd - Cambisol Haplic Dystrophic tipic; 08 LVAd arg - Latosol Red-Yellow Dystrophic argisolic; 09 PAd lat - Argisol Yellow Dystrophic latosolic; 10 PVAd - Argisol Red-Yellow Dystrophic tipic; 11 PVA ali - Argisol Red-Yellow Alitic tipic; 12 PVAd coe - Argisol Red-Yellow Dystrophic Cohesive abrupt. DF = Degrees of Freedom. CV = Coefficient of Variation. SD = Standard Deviation. Significance levels by test $\mathrm{F}:(* *)=1 \%$ of error. In bold are highlighted the mean clusters positively correlated with cacao quality. 
The group of cropping sites with the highest averages of $\mathrm{Mn}$ content in cacao beans showed values between 26.52 and $28.46 \mathrm{mg} \mathrm{kg}^{-1}$, and the group with the lowest averages showed values between 13.86 and $17.81 \mathrm{mg} \mathrm{kg}^{-1}$ (Table 4). The group with the highest averages of $\mathrm{Fe}$ content showed values between 51.27 and $58.97 \mathrm{mg} \mathrm{kg}^{-1}$, and the group with the lowest averages showed values between 10.95 and $37.43 \mathrm{mg} \mathrm{kg}^{-1}$ (Table 4). The group with the highest averages of $\mathrm{Zn}$ content showed values between 30.10 and $34.54 \mathrm{mg} \mathrm{kg}^{-1}$, and the group with the lowest averages showed values between 24.19 and $28.82 \mathrm{mg} \mathrm{kg}^{-1}$ (Table 4). The highest averages of $\mathrm{Cu}$ content corresponded to the group of cropping sites with values between 15.53 and $19.07 \mathrm{mg} \mathrm{kg}^{-1}$ (Table 4). The Cd content of $1.33 \mathrm{mg} \mathrm{kg}^{-1}$ in dry cacao beans of of $\mathrm{PH}-16$ clone corresponded to the only group of cropping sites with the highest average, and the group of cropping sites with the lowest averages showed values between 0.23 and $0.37 \mathrm{mg}$ $\mathrm{kg}^{-1}$ (Table 4). The highest average of Ba content of $11.23 \mathrm{mg} \mathrm{kg}^{-1}$ in dry cacao beans corresponded to the only group of cropping sites, and the group of cropping sites with the lowest averages showed values between 2.23 and $3.50 \mathrm{mg} \mathrm{kg}^{-1}$ (Table 4).

Table 5 shows the absence of linear correlations with absolute value equal to or higher than 0.50 .

Table 5. Pearson's linear correlation coefficient between micronutrients and potentially toxic elements of dry cacao beans of PH-16 clone

\begin{tabular}{cccccc}
\hline Attribute & $\mathrm{Mn}$ & $\mathrm{Fe}$ & $\mathrm{Zn}$ & $\mathrm{Cu}$ & $\mathrm{Cd}$ \\
\hline $\mathrm{Fe}$ & 0.05 & & & & \\
$\mathrm{Zn}$ & $-0.47^{* *}$ & -0.21 & & & \\
$\mathrm{Cu}$ & 0.18 & 0.06 & -0.07 & & \\
\hline $\mathrm{Cd}$ & -0.05 & -0.08 & 0.10 & -0.15 & 0.18 \\
$\mathrm{Ba}$ & 0.27 & 0.20 & -0.32 & -0.24 & \\
\hline
\end{tabular}

Significance levels by test $\mathrm{F}:(* *)=1 \%$ of error

Table 6 shows the mineral elements of dry cacao beans of PH-16 clone in descending order of contents.

Table 6. Descending order of mineral elements contents of dry cacao beans of PH-16 clone

\begin{tabular}{ccc}
\hline Rank & Mineral & $\mathrm{mg} \mathrm{kg}^{-1}$ \\
\hline $1^{\circ}$ & $\mathrm{N}$ & 26370 \\
$2^{\circ}$ & $\mathrm{K}$ & 7820 \\
$3^{\circ}$ & $\mathrm{Ca}$ & 2700 \\
$4^{\circ}$ & $\mathrm{P}$ & 2660 \\
$5^{\circ}$ & $\mathrm{Mg}$ & 2080 \\
$6^{\circ}$ & $\mathrm{Si}$ & 1440 \\
$7^{\circ}$ & $\mathrm{Fe}$ & 30.37 \\
$8^{\circ}$ & $\mathrm{Zn}$ & 30.06 \\
$9^{\circ}$ & $\mathrm{Cu}$ & 21.94 \\
$10^{\circ}$ & $\mathrm{Mn}$ & 20.82 \\
$11^{\circ}$ & $\mathrm{Ba}$ & 5.17 \\
$12^{\circ}$ & $\mathrm{Cd}$ & 0.55 \\
$13^{\circ}$ & $\mathrm{Pb}$ & - \\
\hline
\end{tabular}

*Lead cannot be detected in cacao beans this study with the range of contents in $\mathrm{mg} \mathrm{kg}^{-1}$, but this does not mean that this mineral element cannot be detected at lower contents as $\mu \mathrm{g} \mathrm{kg}^{-1}$. 


\section{Discussion}

In this study, the overall average of $\mathrm{N}$ content of 26.37 $\mathrm{g} \mathrm{kg}^{-1}$ in dry cacao beans (Table 2) is higher than the average content of $22.85 \mathrm{~g} \mathrm{~kg}^{-1}$ showed in an earlier study with PH-16 clone (Muniz et al., 2013). As other reports (Malavolta et al., 1984; Aikpokpodion, 2010; Muniz, 2013), in this study $\mathrm{N}$ was showed as the most accumulated mineral element in cacao beans (Table 2). $\mathrm{N}$ is the most abundant mineral element in plants, as it is composed of amino acids, proteins, enzymes, coenzymes and nucleotides (Marenco and Lopes, 2009). The published reports showed averages of $\mathrm{P}$ content varying between 1.96 and $5.83 \mathrm{~g} \mathrm{~kg}^{-1}$ in cacao beans (Malavolta et al., 1984; Loureiro, 2016; Pinto, 2013; Afoakwa et al., 2013; Bertoldi et al., 2016; Cinquanta et al.2016), being found in many proteins, coenzymes, nucleic acids and metabolic substrates (Marenco and Lopes, 2009). The overall average of P content of 2.66 $\mathrm{g} \mathrm{kg}^{-1}$ (Table 2) was lower than the average contents typical for the same clone (Pinto, 2013) grown in the sub-humid zone $\left(5.01 \mathrm{~g} \mathrm{~kg}^{-1}\right)$ and the humid zone (5.07 $\left.\mathrm{g} \mathrm{kg}^{-1}\right)$. $\mathrm{P}$ is the fifth mineral nutrient most absorbed by cacao crop and many crops have a deficiency of this element (Souza Júnior et al., 2012). Besides being an essential mineral nutrient for plants, $\mathrm{P}$ is also essential nutrient for humans and animals; therefore, this study highlights the group of cropping sites that support higher P contents in cacao beans (Table 2). These results of $\mathrm{K}$ average contents (Table 2) may indicate the influence of geographical location on the cacao beans mineral composition. It has been reported earlier that cacao beans of PH-16 clone, contained average values of $\mathrm{K}$ content of $14.52 \mathrm{~g} \mathrm{~kg}^{-1}$ in sub-humid zone and $12.31 \mathrm{~g} \mathrm{~kg}^{-1}$ in humid zone (Pinto, 2013), both values are higher than the level observed in this study (Table 2). Worldwide averages of $\mathrm{K}$ content can be found between 5.66 and $25.58 \mathrm{~g} \mathrm{~kg}^{-1}$ in cacao beans (Malavolta et al., 1984; Loureiro, 2016; Pinto, 2013;
Afoakwa et al., 2013; Bertoldi et al., 2016; Cinquanta et al. 2016), making $K$ the most absorbed mineral element in cacao beans (Sodré et al., 2012; Souza Júnior et al., 2012; Pinto, 2013). The availability of $\mathrm{K}$ in the soil is has been correlated with the accumulation of this mineral nutrient in plant tissues of cacao (Souza Júnior et al., 2012). The differences observed in averages of $\mathrm{K}$ content of cacao beans observed in this study (Table 2) may be related to different levels of available soil $\mathrm{K}$ in the various cropping sites (Loureiro, 2016). This study highlights that the cacao quality should be linked with the group of cropping sites with highest averages of $\mathrm{K}$ contents in cacao beans (Table 2).

In an earlier report, the same cacao clone in Bahia state, Brazil, was observed to have averages of $\mathrm{Ca}$ content in cacao beans between $0.58 \mathrm{~g} \mathrm{~kg}^{-1}$ (humid zone) and $0.85 \mathrm{~g} \mathrm{~kg}^{-1}$ (sub-humid zone) (Pinto, 2013); these average of contents were particularly low, and are lower than $\mathrm{Ca}$ contents found in current study (Table 2). Ca storage in plant seeds, in particular vacuoles, is associated with specific demands on processes of meristematic cell division, cell wall formation and stabilization of plasmalemma (Marenco and Lopes, 2009). The literature reports averages of $\mathrm{Ca}$ content between 0.58 to $2.70 \mathrm{~g} \mathrm{~kg}^{-1}$ in cacao beans (Malavolta et al., 1984; Loureiro, 2016; Pinto, 2013; Afoakwa et al., 2013; Bertoldi et al., 2016; Cinquanta et al. 2016). This study highlights the group of cropping sites with highest averages of $\mathrm{Ca}$ content in cacao beans as an aspect of cacao quality (Table 2).

The overall average of $\mathrm{Mg}$ content of $2.08 \mathrm{~g} \mathrm{~kg}^{-1}$ (Table 2) is lower than the average contents observed in an earlier study with PH-16 clone, $3.77 \mathrm{~g} \mathrm{~kg}^{-1}$ in subhumid zone and $3.46 \mathrm{~g} \mathrm{~kg}^{-1}$ in humid zone (Pinto, 2013). In cacao beans, average values of $\mathrm{Mg}$ content may vary between 1.67 and $3.83 \mathrm{~g} \mathrm{~kg}^{-1}$ (Malavolta et al., 1984; Loureiro, 2016; Pinto, 2013; Afoakwa 
et al., 2013; Bertoldi et al., 2016; Cinquanta et al. 2016). Mg is easily translocated from older tissues to new tissues like the seeds and about $70 \%$ of $\mathrm{Mg}$ is present in the vacuoles and serves as a co-transport of anions and organic and inorganic acids (Marenco and Lopes, 2009). The release of $\mathrm{Mg}$ from the clay exchangeable complex in soils is usually lower than the plant demand, which requires large amounts of available $\mathrm{Mg}$ for optimal plant growth. So it is assumed that the levels of this mineral element in cacao beans depends upon the of the relative abundance of this element in the soil solution.

The average of Si content observed in Common cacao beans corresponded to the value of $2.70 \mathrm{~g} \mathrm{~kg}^{-1}$ (Loureiro, 2016) which is higher than the highest Si content of $2.10 \mathrm{~g} \mathrm{~kg}^{-1}$ observed in current study with PH-16 (Table 2). Si was observed in the plant biomass to approximate to the contents of the macronutrients $\mathrm{K}, \mathrm{Ca}, \mathrm{Mg}, \mathrm{S}$ and $\mathrm{P}$. With respect to human health, silicon has been recognized as an essential nutrient for bone formation and maintenance, however, the mechanisms are unclear but evidence exists of its involvement in collagen synthesis and/or stabilization and in matrix mineralization (Jugdaohsingh, 2007). There is still a need for establishment of this element's biological function in human health because this could have important implications for nutrition as a preventative measure (Jugdaohsingh, 2007). Considering the potential benefits of Si to human health, this study highlights the group of cropping sites that have highest averages of Si content in cacao beans (Table 2). Also, it's very interesting, the general benefits of the Si for reducing the damage caused by water deficit (Camargo et al., 2017), to several plants, and ameliorates salt-induced stress (Mahdieh et al., 2015).

The relationships showed in Figure 1 can be explained, from the point of view of the physiology and anatomy of the cacao beans, by the way in which these minerals are stored in plant cells. The cell vacuoles of seeds are important compartments for ions such as $\mathrm{Ca}^{2+}, \mathrm{K}^{+}, \mathrm{Cl}^{-}, \mathrm{Na}^{+}, \mathrm{HPO}_{4}^{2-}$ sugars, organic acids and amino acids (Marenco and Lopes, 2009). Therefore, high levels of macronutrients like $\mathrm{K}, \mathrm{P}, \mathrm{Ca}$ and $\mathrm{Mg}$ are expected in the seeds due to the metabolic requirements in the initial process of germination and seedling development (Marenco and Lopes, 2009). In the development process there is a large consumption of ATP (adenosine triphosphate) for synthesis of membrane and cell wall components that directly involve minerals $\mathrm{Ca}$ and $\mathrm{Mg}$ (Marenco and Lopes, 2009).

Clarifying the results of Figure 1, the macronutrients $\mathrm{P}, \mathrm{K}$ and $\mathrm{Mg}$ are required essential nutrients and are highly correlated to each other because of their importance to the biochemical functions that occur naturally in the cacao seeds (Afoakwa et al., 2013). However, it should be considered that during the fermentation process, there is loss of cell membranes of the seeds, which either allows for input and output of these elements, particularly the $\mathrm{K}^{+}$ion, which is not part of any organizational structure of plant tissues.

Figure 1 shows that beans rich in a given macronutrient are also rich in other macronutrients. This can be an effect of the concentration of these elements (Figure 1), that is, the less cacao beans dry matter, consequently, the lower the concentration of nutrients. On the other hand, it can also be a global consequence of the availability of macronutrients in the soil. A soil richer in a macronutrient tends to be richer in the other macronutrients. In addition, an important finding was that nitrogen and silicon showed no significant correlations with absolute value higher than or equal to 0.50 with other mineral elements of cacao beans. The main components represented in biplots $a$ and $b$ of Figure 2 have eigenvalues higher than one, and retain $90 \%$ of the total variance of the data for interpretation based on the averages (Table 4). The PCA represented 
by the graphs a and b of Figure 3 also have eigenvalues higher than one, retaining about $89 \%$ of the total variance of the data (Table 3 ).

In Figure 2a and b, positive correlations were observed between the $\mathrm{K}$ content of cacao beans and site 9 (Argisol Yellow Dystrophic latosolic) in the Cacao System, with an average density of 35 shade trees per hectare (9_Cab_35), and site 10 (Argisol Red-Yellow Dystrophic tipic) in the Cacao Cabruca system with the same average density of 35 shade trees per hectare (10_Cab_35).

The macronutrients $\mathrm{P}$ and $\mathrm{Mg}$ were positively correlated (Figures 2a, 2b, 3a and 3b). Potassium showed a weak positive correlation with $\mathrm{Ca}$ and no correlation with $\mathrm{P}$ and $\mathrm{Mg}$ elements (Figures 2a, 2b, 3a and 3b). Graphically, site 1 (Latosol Yellow Dystrophic cambisolic) in intercropping system Cacao Tree $\mathrm{x}$ Rubber Tree, with an average density of 150 shade trees per hectare (1_CxR_150) and site 2 (Argisol Red-Yellow Dystrophic tipic) in intercropping system Cacao Tree $x$ Erythrina Tree, with an average density of 60 shade trees per hectare (2_CxE_60), have a weak positive correlation with $\mathrm{P}$ and $\mathrm{Mg}$ contents in cacao beans (Figure 2a and b). Also, site 7 (Cambisol Haplic Dystrophic tipic) in Cacao Cabruca system, with an average density of 35 shade trees per hectare (7_Cab_35) and site 8 (Latosol Red-Yellow Dystrophic argisolic) in the Cacao Cabruca system, with an average density of 70 shade trees per hectare (8_Cab_70), showed a weak negative correlation with the $\mathrm{K}$ content in cacao beans (Figure $2 \mathrm{a}$ and $\mathrm{b}$ ). These sites (7 and 8) are close to each other according to geographic coordinates (Figure 2a and b; Table 1).

The site 6 (Argisol Red-Yellow Eutrophic cambisolic) in Cacao Cabruca system, with an average density of 50 shade trees per hectare (6_Cab_50) and site 12 (Argisol Red-Yellow Dystrophic Cohesive abrupt) in the intercropping system Cacao Tree $\mathrm{x}$ Rubber Tree, with an average density of 400 shade trees per hectare (12_CxR_400) showed negative correlations with the same variables $(\mathrm{P}$ and $\mathrm{Mg}$ ) (Figure 2a and $\mathrm{b}$ ).

In relation to the sites by classification of soils (Figure 2a) and by cropping systems (Figure 2b), the variable $\mathrm{K}$ has low correlation with variable $\mathrm{Ca}$ and has no correlation with the $\mathrm{P}$ and $\mathrm{Mg}$. However, the analysis of all observations associated with soil classes (Argisols, Cambisols, and Latosols) and cropping systems (Cacao Cabruca, Cacao x Erythrina Tree, Cacao $\mathrm{x}$ Rubber Tree) show that $\mathrm{K}$ and $\mathrm{Ca}$ are positively correlated (Figure $3 \mathrm{a}$ and $\mathrm{b}$ ). These results of the relationship between $\mathrm{K}$ and $\mathrm{Ca}$ in dry cacao beans approaching the average clusters generated by the Scott-Knott test (Table 2).

Site 9 (Argisol Yellow Dystrophic latosolic) and site 10 (Argisol Red-Yellow Dystrophic tipic) were positively correlated with the K (Figure 2a and b). Sites 7 and 8 were negatively correlated with the same macronutrient (Figure 2a and b). Sites 9 and 10 are close to each other according to geographic coordinates (Figure 2a and b; Table 1). Sites 7 and 8 are also close geographically (Figure 2a and b; Table 1). These correlations suggest that environmental differences can influence the $\mathrm{K}$ content in the cacao beans (Figure 2).

The majority of observations of the macronutrient contents of $\mathrm{K}, \mathrm{Ca}, \mathrm{P}$ and $\mathrm{Mg}$ proved uncorrelated or weak positive correlations, as well as with negative correlations with the observations corresponding to all samples of the cultivation sites represented by soil classes and cropping systems (Figure $3 \mathrm{a}$ and $\mathrm{b}$ ). The availability of mineral nutrients is also associated with land management in the study sites, in which we highlight soil acidity correction techniques and fertilization. (1) Historically, the areas of Cacao Cabruca have not received proper soil management, in contrast to intercropping systems such as the Cacao x Rubber Tree, in which the application of the fertilizer is 
more intensive. However, multivariate exploratory analysis suggested that both cropping systems required more attention as the supply of these mineral nutrients could be reflected in cacao quality (Figure 2). Considering its multiple trees natural consortium, the cabruca system should be studied to correlate the root exudates on the nutrient and toxic elements of edaphic environment, based on the subject discussed by Violante and Caporale (2015).

It has been reported earlier that cacao genotype PH-16 accumulated $28.65 \mathrm{mg} \mathrm{kg}^{-1}$ of $\mathrm{Mn}$ in humid climate zone, and approximately double that value, $64.56 \mathrm{mg} \mathrm{kg}^{-1}$, was observed in sub-humid climate zone (Pinto, 2013). These Mn accumulations were higher than the ones observed in current study (Table 4). The literature showed that the Mn content varies between 12.23 to $64.56 \mathrm{mg} \mathrm{kg}^{-1}$ in dry cacao beans (Malavolta et al., 1984; Olaofe et al., 1987; Aikpokpodion, 2010; Pinto, 2013; Loureiro, 2016; Yanus et al. 2014; Bertoldi et al., 2016; Cinquanta et al. 2016). In cacao leaves, very high $\mathrm{Mn}$ accumulation has been observed and can even accumulate higher than $1000 \mathrm{mg} \mathrm{kg}^{-1}$, yet, plants did not display any toxicity symptoms (Souza Júnior et al., 2012). Manganese plays an important role in a number of physiologic processes as a constituent of multiple enzymes and an activator of other enzymes. Because of the potential for toxicity and the lack of information regarding benefit, manganese supplementation beyond $100 \%$ of the daily values (DV) $\left(2 \mathrm{mg} \mathrm{day}^{-1}\right)$ is not recommended (LPI, 2010). There is presently no evidence that the consumption of a manganese-rich plant-based (20 mg day $\left.{ }^{-1}\right)$ diet results in manganese toxicity (FNB, 2001). By its nutritional importance for human health, this study highlights the group of cropping sites that produce cacao beans with highest averages of Mn content (Table 4).

The overall average of Fe content of $10.38 \mathrm{mg} \mathrm{kg}^{-1}$ (Table 4) was lower than the average contents of
$19.36 \mathrm{mg} \mathrm{kg}^{-1}$ (sub-humid zone) and $10.81 \mathrm{mg} \mathrm{kg}^{-1}$ (humid zone) observed in cacao beans of PH-16 clone grown in the same region as this current experiment (Pinto, 2013), showing the environmental influence on the Fe contents in dry cacao beans. The literature shows Fe contents varying between 10.38 and $183 \mathrm{mg} \mathrm{kg}^{-1}$ in cacao beans (Malavolta et al., 1984; Olaofe et al., 1987; Aikpokpodion, 2010; Pinto, 2013; Afoakwa et al., 2013; Loureiro, 2016; Bertoldi et al., 2016; Cinquanta et al. 2016). Fe accumulation is significant in cacao fruits, particularly in growing conditions in tropical soils. Fe is an important human mineral nutrient, whose deficiency in human populations is still a challenge to global public health (Stoltzfus, 2001). This study highlights the group of cropping sites that produce cacao beans with higher Fe content in cacao beans (Table 4).

Another study with clone PH-16 (Pinto, 2013) showed averages of $\mathrm{Zn}$ content of $18.92 \mathrm{mg} \mathrm{kg}^{-1}$ in the humid zone and $34.28 \mathrm{mg} \mathrm{kg}^{-1}$ in the sub-humid zone, considering that the level of $\mathrm{Zn}$ values found in the present study was higher (Table 4). The averages of $\mathrm{Zn}$ content observed in dry cacao beans varied between 18.92 and $109 \mathrm{mg} \mathrm{kg}^{-1}$ (Malavolta et al., 1984; Olaofe et al., 1987; Aikpokpodion, 2010; Aikpokpodion et al., 2013; Pinto, 2013; Loureiro, 2016; Bertoldi et al., 2016; Cinquanta et al. 2016). It is has been reported that deficiency of $\mathrm{Zn}$ is very frequent in cacao plantations of southern Bahia (Souza Júnior et al., 2012), so the export of this mineral element in the cacao beans requires special attention (Muniz et al., 2013). Zinc is mineral nutrient that is essential for human health, and it has been estimated that 2 billion people on the planet are zinc deficient (Prasad, 2012). Knowledge of zinc toxicity in humans is minimal (Islam et al., 2007). The nutritional importance of $\mathrm{Zn}$ both for cacao trees and for humans highlights the group of cropping sites that produce cacao beans with higher $\mathrm{Zn}$ contents (Table 4). 
The averages of $\mathrm{Cu}$ contents found in this study (Table 4) were highest than the average contents observed in an earlier study with PH-16 clone, $14.91 \mathrm{mg} \mathrm{kg}^{-1}$ in sub-humid zone and $9.71 \mathrm{mg} \mathrm{kg}^{-1}$ in humid zone (Pinto, 2013). The $\mathrm{Cu}$ contents observed in dry cacao beans vary between 2.4 and $88 \mathrm{mg} \mathrm{kg}^{-1}$ (Malavolta et al., 1984; Lee and Low, 1985; Olaofe et al., 1987; Aikpokpodion, 2010; Aikpokpodion et al., 2013; Pinto, 2013; Loureiro, 2016; Bertoldi et al., 2016; Cinquanta et al. 2016), with the greatest variation values of all the mineral elements mentioned. In the vegetative part of the plant, $\mathrm{Cu}$ participates in various physiological processes such as redox, respiration, carbohydrate distribution, fixing and reduction of $\mathrm{N}$ protein for metabolism and cell walls and nucleic acids (Marenco and Lopes, 2009). Cu deficiency has been reported in cacao plantations (Souza Júnior et $a l ., 1999)$, denoting that this micronutrient is quite in demand by cacao trees in this region.

$\mathrm{Cu}$ also requires attention because it can be considered a potentially toxic element (PTE) at high concentrations to human and animal health (Aikpokpodion et al., 2013; Oka et al., 2014). However, both $\mathrm{Cu}$ and other minerals like $\mathrm{K}, \mathrm{Ca}$ and $\mathrm{Mg}$ are acknowledged to contribute to cardiovascular risk reduction (Fernández-Murga et al., 2011). The contents detected in this study (Table 4) were far lower than the European Union (EU, 2013) has set the maximum residue limit of $\mathrm{Cu}$ in foods by $50 \mathrm{mg} \mathrm{kg}^{-1}$. Considering the risk of increasing $\mathrm{Cu}$ contents in cacao beans free from a possible nutritional deficiency with this element, and assuming the optimum content of this nutrient, this study highlights the group of cropping sites with the lowest content of $\mathrm{Cu}$ in the cacao beans (Table 4).

As with $\mathrm{Cu}$, a group of cropping sites stands out in the current study that produce lower $\mathrm{Cd}$ content in dry cacao beans (Table 4). The Cd contents observed in dry cacao beans are known to vary between 0.06 and $1.39 \mathrm{mg} \mathrm{kg}^{-1}$ (Lee and Low, 1985; Ekpa et al., 1993; Aikpokpodion et al., 2013; Loureiro, 2016; Yanus et al. 2014; Bertoldi et al., 2016). Cadmium is a PTE for human and animal health; therefore, European Union has established a limit of $0.60 \mathrm{mg}$ $\mathrm{kg}^{-1}$ of $\mathrm{Cd}$ for dry cacao beans (Aikpokpodion et al., 2013; EU, 2014). Cd accumulation in plant tissues is proportional to its availability in the soil. These cropping sites could be selected as potential sites to produce cacao beans with reduced $\mathrm{Cd}$ to reduce the risk that this element can cause to human health (Table 4). The value of $1.33 \mathrm{mg} \mathrm{kg}^{-1}$ observed in Argisol Red-Yellow Alitic tipic (Table 4) is about two times above the $0.60 \mathrm{mg} \mathrm{kg}^{-1}$ limit for Cd in dry cacao beans (EU, 2014). In addition, the average contents found in site 2 (Argisol Red-Yellow Dystrophic tipic), site 3 (Argisol Red-Yellow Dystrophic abrupt) and site 8 (Latosol Red-Yellow Dystrophic argisolic) (Table 4) are above this limit.

$\mathrm{Ba}$ contents found in this study are equivalent to those of other micronutrients (Table 4). This study highlights the group of cropping sites that produce cacao beans with the lowest $\mathrm{Ba}$ content as an aspect of cacao quality (Table 4). The range of Ba content of 4.40 to $8.90 \mathrm{mg} \mathrm{kg}^{-1}$ reported in dry cacao beans of Common cacao (Forastero) (Loureiro, 2016), was lowest that the range of 1.90 to $11.70 \mathrm{mg} \mathrm{kg}^{-1}$ found in this study (Table 4). The Agency for Toxic Substances and Disease Registry (ATSDR, 2007) includes Ba in the list of PTE that offer risk to human health. The soil is the main natural source of $\mathrm{Ba}$ found in plant organisms. Cinquanta et al. (2016) reported this value of $3.3 \mathrm{mg}$ $\mathrm{kg}^{-1}$ of Ba content in cocoa beans. In the study of Bertoldi et al. (2016), the averages of Ba content related in cocoa beans were reported in samples from different geographic origins: $9.14 \mathrm{mg} \mathrm{kg}^{-1}$ (West Africa, $\mathrm{n}=21$ ), $22.2 \mathrm{mg} \mathrm{kg}^{-1}$ (East Africa, $\mathrm{n}=8$ ), $5.94 \mathrm{mg} \mathrm{kg-1}$ (Asia, $\mathrm{n}=8), 8.55 \mathrm{mg} \mathrm{kg}^{-1}$ (South America, $\left.\mathrm{n}=14\right), 5.86 \mathrm{mg}$ $\mathrm{kg}^{-1}$ (Central America, $\left.\mathrm{n}=10\right)$. The values found in this 
study are close to those reported in previous studies (Cinquanta et al. 2016; Bertoldi et al., 2016), except for the value found in East Africa (Bertoldi et al., 2016), which corresponds to twice as many times as the highest $\mathrm{Ba}$ content in the almonds of the $\mathrm{PH}-$ 16 clone.

Variations in the contents of $\mathrm{Mn}, \mathrm{Fe}, \mathrm{Zn}, \mathrm{Cu}, \mathrm{Cd}$ and $\mathrm{Ba}$ in cacao beans relative to the cropping sites and their respective geographical location are independent (Table 4). Because these mineral elements do not show any significant correlations with each other (Table 5), it is possible that clusters generated between these elemental contents in dry cacao beans might have been influenced by environmental factors in addition to soil and crop management.

It can be seen in Table 6 the mineral nutrient contents in plant tissues of elements commonly associated with the degree of importance for sufficient/ adequate growth and development and needed for metabolic functions (Marenco and Lopes, 2009). In the current study, the requirement of $\mathrm{K}$ in cacao beans of PH-16 clone is approximately two times higher than that observed for other macronutrients $\mathrm{P}, \mathrm{Ca}$ and $\mathrm{Mg}$ (Table 6). Si, although it is not an essential element for plants, appeared in cacao beans at contents close to that of essential macronutrients (Table 6). Among the PTE quantified in dry cacao beans of PH-16 clone, stands out is Ba with levels close to essential micronutrient contents (Table 6). Content of $\mathrm{Pb}$ was at very low levels and was below detection limit (Table 6).

\section{Conclusions}

With the exception of nitrogen, $\mathrm{K}$ was the mineral element most accumulated by cacao beans of PH-16 clone. The contents of $\mathrm{P}, \mathrm{K}$ and $\mathrm{Ca}$ in dry cacao beans were positively correlated with each other and showed similar differences in their contents in relationship to the different cropping study sites. The variation of $\mathrm{Mg}$ content in dry cacao beans was not sufficient to detect differences between the cropping sites, however this element showed high positive correlation with the $\mathrm{P}, \mathrm{K}$ and $\mathrm{Ca}$ contents. The sites that correspond to soils Cambisol Haplic Dystrophic tipic and Latosol Red-Yellow Dystrophic argisolic, which were geographically close to each other, were positively correlated with $\mathrm{P}$ and $\mathrm{Mg}$ contents in dry cacao beans. The Argisol Dystrophic latosolic and Argisol Red-Yellow Dystrophic tipic, which are geographically close, were positively correlated with the $\mathrm{K}$ contents of dry cacao beans. The multivariate analysis of the $\mathrm{K}, \mathrm{Ca}, \mathrm{P}$ and $\mathrm{Mg}$ in dry cacao beans suggested that the supply of macronutrients could be deficient in most cropping sites. Silicon content in cacao beans was proportionately close to the content of essential macronutrients. The variations in $\mathrm{Mn}, \mathrm{Fe}$, $\mathrm{Zn}, \mathrm{Cu}, \mathrm{Cd}$ and $\mathrm{Ba}$ contents were independent, since these mineral elements did not present significant correlations between with each other, therefore, the contents differed for each cropping site. Barium contents observed in this study correspond to contents found in other micronutrients. Cadmium content of cacao beans observed in four sites were above the limit of $0.60 \mathrm{mg} \mathrm{kg}^{-1}$, established by the European Union.

\section{Acknowledgements}

We thank Dr. Marshall Elson for excellent review of this paper.

This paper is part of the project "Linking soil quality and cacao quality in Bahia, Brazil". To run fundamental steps of this research, the corresponding author was supported by the Brazilian National Council for Scientific and Technological Development (CNPq) with a Postdoctoral fellowship. 


\section{References}

Afoakwa, E.O., Quao, J., Takrama, J., Budu, A.S., Saalia, F.K. 2013. Chemical composition and physical quality characteristics of Ghanaian cocoa beans as affected by pulp pre-conditioning and fermentation. J. Food Sci. Technol. 50, 1097-1105.

Aikpokpodion, P. 2010. Nutrients dynamics in cocoa soils, leaf and beans in Ondo State, Nigeria. J. Agri. Sci. 1, 1-9.

Aikpokpodion, P.E., Atewolara-Odule, O.C., Osobamiro, T., Ademola, S.M. 2013. A survey of copper, lead, cadmium and zinc residues in cocoa beans obtained from selected plantations in Nigeria. J. Chem. Pharm. Res. 5, 88-98.

Araujo, Q.R., Fernandes, C.A.F., Ribeiro, D.O., Efraim, P., Steinmacher, D., Lieberei, R., Bastide, P., Araujo, T.G. 2014. Cocoa Quality Index - a Proposal. Food Control. 46, 49-54.

ATSDR. 2007. Toxicological profile for barium and barium compounds. U.S. Department of Health and Human Services, Public Health Service, ATSDR, U.S. 231 p.

Bertoldi, D., Barbero, A., Camin, F., Caligiani, A., Larcher, R. 2016. Multielemental fingerprinting and geographic traceability of Theobroma cacao beans and cocoa products. Food Control. $65,46-53$.

Camargo, M.S., Bezerra, B.K.L., Vitti, A.C., Silva, M.A., Oliveira, A.L. 2017. Silicon fertilization reduces the deleterious effects of water deficit in sugarcane. J. Soil Sci. Plant Nutr. 17, 99-111.

Carmo, C.A.F. de S. do, Araújo, W.S. de, Bernardi, A.C. de C., Saldanha, M.F.C. 2000. Método de análise de tecidos vegetais (Circular Técnica, 6). Embrapa Solos, Rio de Janeiro, RJ. 41 p.
Cinquanta, L., Di Cesare, Cinzia., Manoni, R., Piano, A., Roberti, P., Salvatori, G. 2016. Mineral essential elements for nutrition in different chocolate products. Int. J. Food Sci. Nutr. 65, 46-53.

Colombo, M.L.; Pinorini-Godly, M.T., Conti, A. Botany and Pharmacognosy of the Cacao Tree. In: Paoletti R, Poli A, Conti A, Visioli F. 2012. Chocolate and health. Milano (Italy): SpringerVerlag Italia Srl, pp: 41-62.

Cruz, J.F.M., Bacelar, L.P., Eduardo, S.S., Silva, B.E 2013. Assessment of the fermentative process from different cocoa cultivars produced in Southern Bahia, Brazil. Afr. J. Biotechnol. 12, 52185225 .

Ekpa, O., Akpan, A.A., Udo, A.E. 1993. Industrially important parameters and mineral composition of cocoa: a comparative study of cocoa pod husks and beans from plantations in South-Eastern Nigeria. J. Sci. Food Agric. 61, 47-50.

EU. 2014. Commission Regulation (EU) No 488/2014 of 12 May 2014 amending Regulation (EC) No $1881 / 2006$ as regards maximum levels of cadmium in foodstuffs. Off. J. Eur. Union. 138, 75-79.

EU. 2013. Commission Regulation (EU) No 1275/2013 of 6 December 2013 amending Annex I to Directive 2002/32/EC of the European Parliament and of the Council as regards maximum levels for arsenic, cadmium, lead, nitrites, volatile mustard oil and harmful botanical impurities. Off. J. Eur. Union. 328, 86-92.

FAO. 2017. FAOSTAT. Food and agriculture data. Production quantities of cocoa, beans by country. Average 1994-2014. http://www.fao.org/faostat/ en/\#data/QC/visualize. Accessed 12 March 2017.

Faria, J.C., Demétrio, C.G.B., Allaman, I.B. 2015. Package 'bpca'. Biplot of multivariate data based on Principal Components Analysis. R package version 1.2-2. $\mathrm{R}$ : The $\mathrm{R}$ Project for Statistical Computing, $45 \mathrm{p}$. 
Fernández-Murga, L., Tarín, J.J., García-Perez, M.A., Cano, A. 2011. The impact of chocolate on cardiovascular health. Maturitas. 69, 312-321.

FNB. 2001. Manganese. Dietary reference intakes for vitamin $\mathrm{A}$, vitamin $\mathrm{K}$, boron, chromium, copper, iodine, iron, manganese, molybdenum, nickel, silicon, vanadium, and zinc. National Academy Press, Washington, DC, pp: 394-419.

Islam, E. ul, Yang, X., He, Z., Mahmood, Q. 2007. Assessing potential dietary toxicity of heavy metals in selected vegetables and food crops. J. Zhejiang Univ. Sci. B. 8, 1-13.

Jugdaohsingh, R. 2007. Silicon and bone health. J. Nutr. Heal. Aging. 11, 99-110.

Kohiyama, M., Kanematsu, H., Niiya, I. 1992. Heavy Metals, Particularly Nickel, Contained in Cacao Beans and Chocolate. J. Japanese Soc. Food Sci. Technol. 39, 596-600.

Korndörfer, G.H., Pereira, H.S., Nolla, A. 2004. Análise de silício: solo, planta e fertilizante (Technical Bulletin, 2). Universidade Federal de Uberlândia, Uberlândia, Minas Gerais, 23 p.

Lee, C.K., Low, K.S. 1985. Determination of cadmium, lead, copper and arsenic in raw cocoa, semifinished and finished chocolate products. Pertanika. 8, 243-248.

LPI. 2010. Micronutrient Information Center. Manganese. Oregon State University. http://lpi.oregonstate. edu/book/export/html/261 Accessed 25 Oct 2016.

Loureiro, G.A.H.A., Araujo, Q.R., Sodré, G.A., Valle, R.R., Souza Jr, J.O., Ramos, E.M.L.S., Comerford, N.B., Grierson, P.F. 2016. Cacao quality: Highlighting selected attributes. Food Rev. Int. 1-24.

Mahdieh, M., Habibollahi, N., Amirjani, M.R., Abnosi, M.R., Ghorbanpour, M. 2015. Exogenous silicon nutrition ameliorates salt-induced stress by improving growth and efficiency of PSII in Oryza sativa L. cultivars. J. Soil Sci. Plant Nutr. 15, 1050-1060.
Malavolta, E., Malavolta, M., Cabral, C. 1984. Nota sobre as exigências minerais do cacaueiro. An. Esc. Super. Agric. Luiz de Queiroz. 41, 243-255.

Marenco, R.A, Lopes, N.F. 2009. Fisiologia Vegetal: fotossíntese, respiração, relações hídricas e nutrição mineral. UFV, Viçosa, Minas Gerais, 451 p.

Muniz, M.R.A., Silveira, R.L.V. de A., Santos, P.S.R. dos, Malta, A., Sorice, L.S.D. 2013. Exportação de nutrientes pelos frutos de cacau de diferentes clones cultivados nas Fazendas Reunidas Vale do Juliana. Addubare RR. Agroflorestal. 24, 5-9.

Oka, G.A., Thomas, L., Lavkulich, L.M. 2014. Soil assessment for urban agriculture: a Vancouver case study. J. Soil Sci. Plant Nutr. 14, 657-669.

Olaofe, O., Oladeji, E.O., Ayodeji, O.I. 1987. Metal contents of some cocoa beans produced in Ondo State, Nigeria. J. Sci. Food Agric. 41, 241-244.

Pinto, F.C. 2013. Fertilidade do solo e partição de nutrientes em cacaueiros. Dissertation, Universidade Estadual de Santa Cruz, Ilhéus, Bahia, Brazil, $108 \mathrm{p}$.

Prasad, A.S. 2012. Discovery of human zinc deficiency: 50 years later. J. Trace Elem. Med. Biol. 26, 66-69.

R Development Core Team. 2016. R: A language and environment for statistical computing. Viena, Austria. R Foundation for Statistical Computing. ISBN 3-900051-07-0. http://www.r-project.org. Accessed 10 Oct 2016

Santos, H.G. dos, Jacomine, P.K.T., Anjos, L.H.C. dos, Oliveira, V.Á. de, Lumbreras, J.F., Coelho, M.R.; Almeida, J.A. de, Cunha, T.J.F., Oliveira, J.B. de (2013) Sistema Brasileiro de Classificação de Solos. Embrapa, Brasília, DF, 353 p.

Sodré, G.A., Venturini, M.T., Ribeiro, D.O., Marrocos, P.C.L. 2012. Extrato da casca do fruto do cacaueiro como fertilizante potássico no crescimento de mudas de cacaueiro. Rev. Bras. Frutic. 34, 881-887. 
Souza Júnior, J.O., Mello, J., Alvarez, V., Neves, J. (1999). Produtividade do cacaueiro em função de características do solo. I. Características químicas. R. Bras. Ci. Solo. 23, 863-872.

Souza Júnior, J.O., Menezes, A.A., Sodré, G.A., Gattward, J.N., Dantas, P.A.S., Neto, R.O.C (2012) Diagnose foliar na cultura do cacau. In: Prado, R.M. (ed). Nutrição de plantas: diagnose foliar em fruteiras. FCAV/CAPES/FAPESB/ CNPq, Jaboticabal, São Paulo, pp: 443-476.
Stoltzfus, R.J. 2001. Defining iron-deficiency anemia in public health terms: A time for reflection. J. Nutr. 131, 565S-567S.

Violante, A., Caporale, A.G. 2015. Biogeochemical processes at soil-root interface. J. Soil Sci. Plant Nutr. 15, 422-448.

Yanus, R.L., Sela, H., Borojovich, E.J.C.; Zakon, Y., Saphier, M., Nikolski, A., Gutflais, E., Lorber, A., Karpas, Zeev. 2014. Trace elements in cocoa solids and chocolate: An ICPMS study. Talanta, 119, 1-4. 